\title{
Anxiety and Healthy Eating
}

\author{
Inês Gaspar* \\ Psychologist at Inês Gaspar Psychology and Mindfulness, Amsterdam-Oost, Netherlands
}

Submission: September 09, 2019; Published: October 3, 2019

*Corresponding author: Inês Gaspar, Psychologist at Inês Gaspar Psychology and Mindfulness, Amsterdam-Oost, Netherlands

\begin{abstract}
Nowadays, food has been demonstrating its importance for the prevention of several diseases namely in mental disorders like anxiety. Further, chemical-mediated therapy is essential in choosing healthy habits and healthy lifestyles more generally. It is these changes in daily life that will influence among other focuses the prevention of mental disorders.

Keywords: Mental disorders; Nutrition; Anxiety
\end{abstract}

\section{Introduction}

Common mental disorders, according to the concept created by Goldberg \& Huxley are characterized by a set of nonpsychotic symptoms such as insomnia, fatigue, irritability, forgetfulness, difficulty concentrating and somatic complaints, which designate situations of mental distress. Which are not covered by international diagnostic criteria [1]. This type of disturbance can affect the quality of life of affected individuals, also affecting the economic costs to society, especially the indirect costs related to absenteeism due to illness, premature retirement and early death [1]. In addition to the fact that depressive disorders may influence the results of the comorbidity of medical diseases such as heart problems, diabetes and cancer and individuals susceptible to original family dysfunctions, such as risks of physical or mental illness [1]. Thus, constituting these psychological disorders and one of the biggest public health problems worldwide [1].

Worldwide, the prevalence of mental health problems is high [1], according to the Portuguese Society of Psychiatry and Mental Health, $12 \%$ of diseases worldwide, which rises to $23 \%$ in the exposed countries. In Portugal, more than one fifth of Portuguese suffer from a psychiatric disorder (22.9\%), ranking second in the country with the highest prevalence of psychiatric illness in Europe. Among these disorders, anxiety has a higher prevalence (16.5\%). Generalized anxiety disorder is a severe psychiatric condition that can negatively affect a patient's quality of life and disrupt important activities of daily living [2,3]. Patients with this mental disorder have excessive anxiety about common everyday situations [3]. Anxiety is intrusive, causes distress or functional impairment, and often multiple domains, and is often associated with physical symptoms such as sleep disturbance, restlessness, muscle tension, gastrointestinal symptoms, and chronic headaches [3].

As it targets internationally for the treatment of generalized anxiety, selective serotonin reuptake inhibitors, serotonin and norepinephrine reuptake inhibitors and pregabalin are recommended as first-line options because of their maintenance and good safety testing, with benzodiazepines as diazepam as options. second row [3]. As has been suggested that missed diagnosis rates and misdiagnosis are high, with symptoms often attributed to causal causes, requiring a wide differential and caution to identify confounding variables and common conditions [2]. Although therapy is more incisive at the pharmacotherapy level, there are data demonstrating changes in lifestyle, especially in eating habits, which may be a modifiable risk factor for mental illness $[4,5]$. These mental disorders are leveraged for the occurrence of other related diseases and, therefore, are essential for treatment and prevention [5].

\section{Discussion}

Mental illnesses have been related to eating, and these affective disorders may increase, and it is therefore essential to understand how they can be prevented $[6,7,4]$. These mental illnesses include depression, anxiety, representing a significant portion of global disability and a social, economic and health burden [4]. The use of nutrition as one of the preventive measures for mental health has grown exponentially today [8]. The human brain uses a substantial portion of the body's total energy and nutrient intake, and there is a strong influence on 
brain structure and function by the ingested nutrients, as well as affecting neurodevelopment and neurotrophic function [5].

Opie's top five dietary recommendations for improving mental health are compliance with traditional dietary standards such as the Mediterranean diet, increased consumption of fruits, vegetables, cereals, nuts and seeds, increased consumption of rich foods. in omega-3 fatty acids, replacing unhealthy foods with healthy nutritious foods, limiting the intake of processed foods, and being aware of probiotic intestinal bacteria $[8,9]$. Possible biological changes related to mental disorders include inflammation, oxidation [4]. Therefore, it is important to eat the foods mentioned above, avoiding unhealthy diets, rich in processed foods, high in fat and high in sugar in adolescence and adulthood as they are positively associated with common mental disorders, anxiety [4].

\section{Conclusion}

The area of nutraceutical related to the prevention of mental disorders, namely generalized anxiety, has been showing a growing importance in this field. Demonstrating focus on the biological pathways that mediate the observed relationships between diet, nutrition and mental health are pointing to the immune system, oxidative biology, brain plasticity and the microbiome-gut-brain axis as major targets for nutritional interventions. By letting us understand that what we overeat is as important as what we do not eating enough, as well as the kind of food choices we make.

\section{References}

1. Murcho N, Pacheco E, Jesus SND (2016) Transtornos mentais comuns nos Cuidados de Saúde Primários: Um estudo de revisão. Revista Portuguesa de Enfermagem de Saúde Mental (15): 30-36.

2. Er I (2015) Diagnosis and management of generalized anxiety disorder and panic disorder in adults. Am Fam Physician 91(9): 617-624.

3. Maron E, Nutt D (2017) Biological markers of generalized anxiety disorder. Dialogues in clinical neuroscience 19(2): 147.

4. Marx W, Moseley G, Berk M, Jacka F (2017) Nutritional psychiatry: the present state of the evidence. Proc Nutr Soc 76(4): 427-436.

5. Aparicio-Ugarriza R, Díaz ÁE, Palacios G, del Mar Bibiloni M, Julibert A, et al. (2018) Association between blood marker analyses regarding physical fitness levels in Spanish older adults: A cross-sectional study from the PHYSMED project. PLoS one 13(10): e0206307.

6. Masana MF, Tyrovolas S, Kolia N, Chrysohoou C, Skoumas J, et al. (2019) Dietary Patterns and Their Association with Anxiety Symptoms among Older Adults: The ATTICA Study. Nutrients 11(6): 1250.

7. Hernando-Requejo V (2018) Patología neurológica por déficit de vitaminas del grupo B: tiamina, folato y cobalamina. Nutrición Hospitalaria 35(6): 54-59.

8. Owen L, Corfe B (2017) The role of diet and nutrition on mental health and wellbeing. Proc Nutr Soc 76(4): 425-426.

9. Jacka FN (2017) Nutritional psychiatry: where to next? E Biomedicine 17: 24-29.

Your next submission with Juniper Publishers will reach you the below assets

- Quality Editorial service

- Swift Peer Review

- Reprints availability

- E-prints Service

- Manuscript Podcast for convenient understanding

- Global attainment for your research

- Manuscript accessibility in different formats

( Pdf, E-pub, Full Text, Audio)

- Unceasing customer service

Track the below URL for one-step submission https://juniperpublishers.com/online-submission.php 